\title{
The Description of Solomon's Wedding: Song 3:6-61 as a Key to the Overall Understanding of the Song of Songs
}

\author{
Annette Schellenberg \\ Institut für Alttestamentliche Wissenschaft und Biblische Archäologie \\ Evangelisch-Theologische Fakultät der Universität Wien \\ annette.schellenberg@univie.ac.at
}

\begin{abstract}
This article argues that Song of Songs $3: 7-71$ is a mocking song about King Solomon and was not originally connected with $3: 6$. After presenting aspects of $3: 7-71$ that might convey criticism of Solomon, the thesis is further substantiated by observations showing that taking Solomon as a cipher for the nonroyal human lover or a divine lover does not work in this passage. The article concludes by pointing out some consequences of this analysis for the overall understanding of the Song.
\end{abstract}

\section{Keywords}

Song of Songs 3:6-61 - Solomon - wedding - divine lover - allegorical interpretation mocking song - composition history - juxtaposition - entertainment

One of the most controversial passages in the Song of Songs is $3: 6-61$. The verses contain several difficulties and thus leave room for diverse interpretations. Taking up observations from other scholars, in this article I will argue that most likely 3:7-71 is a mocking song about Solomon that originally was not connected with $3: 6 .{ }^{1}$ I will support my thesis both with observations about the text that make such a reading likely and with a critical evaluation of alternative

1 Some scholars further differentiate between 3:7-7;3:9-90, and 3:11, and treat them as three independent units. However, as all of them mention Solomon $(3: 7,9,11)$ and can be connected with his palanquin/wedding, 3:7-71 is read as one unit in the following. 
explanations. More concretely, I will show the difficulties inherent in interpretations that take the name Solomon in 3:7-71 to be a cipher for the (human) male lover of other passages in the Song or for God/the Messiah. Beyond 3:6-61, these observations are crucial for the overall understanding of the Song, as I will outline in the last part of this article.

\section{1 \\ Song 3:7-71 as a Mocking Song about King Solomon}

The thesis that Song 3:7-71 (or 3:6-61) is a mocking song about Solomon is not new. The midrash contains a snide comment about Solomon lying fearfully in bed (Shir Rab. 1:1); and Ibn Ezra (eleventh-twelfth century CE) highlighted the contrast between the behavior of Solomon, which is strange in some way, and the more heroic and less pretentious behavior of the woman and the man, the true lovers of the song. ${ }^{2}$ Following these early interpreters, many others have observed that the passage includes critical irony. ${ }^{3}$ Most elaborately, this view has been advanced by Yair Zakovitch and Elisabeth Birnbaum, who both argue - and I agree - that in this passage (as in 8:11-12), King Solomon is not a cipher but indeed refers to the famous king of the past, who is ridiculed. ${ }^{4}$

Primarily, this interpretation is based on observations that suggest that the description of Solomon is positive only on a first glance, conveying irony and criticism upon a closer look. A first-time neutral recipients (readers, audience) might be irritated by 3:7, where Solomon is introduced via his "bed" (מִטָה). According to the traditional understanding of the passage, this bed is in fact his palanquin, coming up from the wilderness $(3: 6)$ and described in more detail in 3:9-9o. However, even if one follows this reading (on the problems of reading 3:7 as the continuation of 3:6, see below, 3), it remains striking that 3:7-7 focuses not on Solomon but on his palanquin ${ }^{6}$ and the soldiers around

2 See Fox, pp. 122-223; Graetz, p. 153; Gottlieb, pp. 118-819.

3 See Gebhardt, p. 6o; Gottlieb, pp. 118-820; Graetz, pp. 152-253; Heinevetter, p. 113; LaCocque, pp. 100-0o1; Provan, pp. 152-258; Whedbee, pp. 267-768; further Nissinen, p. 254, n. 18 with a reference to Pekka Särkiö, whose book was not available to me.

4 See Birnbaum, pp. 256-661; Zakovitch, 2004, pp. 173-38o, both with similar observations than those collected below. Gordis has also argued that Solomon indeed stands for King Solomon. However, he did not consider humor and criticism but instead proposed that 3:6-61 was "perhaps the oldest poem" in the Song and was "composed in honor of one of the marriages of King Solomon" (Gordis, p. 270).

5 See Birnbaum, pp. 257-758; Zakovitch, 2004, p. 173.

6 Indirectly, the irritation is reflected in Heereman's modification of the Song to "Behold King Solomon" (thus the title of Heereman, 2016 and Heereman, 2018). Apparently she did not feel comfortable keeping the Song's "Behold Solomon's bed!" 
it and that the palanquin is first introduced as a bed. Later in the text it becomes clear that the bed is special, with columns and the like (3:9-90). In 3:7, however, this is not yet clear. As the bed is connected with Solomon, recipients might think of a luxurious couch (Esth 1:6; Amos 6:4). Nonetheless, it remains true that the text mentions not a throne or the like but only an ordinary bed, an object on which humans regularly lie.

The mention of Solomon's bed thus leads to the question of who is occupying it (to use a more neutral verb that also allows the audience to imagine reclining or sitting, more compatible with the notion of a palanquin). Song 3:7-7 mentions the warriors standing around the bed/palanquin but leaves open who is in it. As 3:6 opens with a question that aims at a woman, some scholars suggest the occupant is Solomon's bride. ${ }^{7}$ Others think it is Solomon (see $3: 11)^{8}$ or Solomon and his bride together. ${ }^{9}$ Or recipients might take the text's silence on the question as an indication that the bed/palanquin is empty. For all of these explanations, however, the mention of sixty warriors standing around the bed/palanquin triggers the next question: ${ }^{10}$ the text describes the warriors as heavily armed ${ }^{11}$ and mentions "terrors in the nights". Following the traditional reading and imagining that the bed/palanquin carries the bride, who is coming from the wilderness, one might be surprised that Solomon is not mentioned among the troop defending her. If Solomon is in the bed/palanquin on his own, recipients might wonder why he is so afraid that he has to surround himself with such a crowd of bodyguards. ${ }^{12}$ This question remains if one imagines him in the bed/palanquin with his bride. ${ }^{13}$ This

7 See Barbiero, pp. 149-951; Gerhards, pp. 233-334; Hess, pp. 118-821; Keel, pp. 120-022.

8 See Exum, pp. 143-345, 148; Fox, p. 124; Hopf, p. 169; Longman, p. 135; Spencer, pp. 75-56.

9 See Assis, pp. 117-718 (though in a more symbolic way).

10 See Birnbaum, pp. 258-859; Graetz, pp. 152-253; LaCocque, pp. 10o-oo1; Provan, p. 155; Zakovitch, 2004, pp. 174-476.

11 The description of the warriors might include some humor and/or criticism as well. Noteworthy in particular is the phrase אִחְזָי חֶרֶב, ordinarily translated as "skilled with (the) sword" or "equipped with sword" or the like. The first translation is supported by the Akkadian cognate $a h \bar{a} z u(m)$, which can mean "to learn" (Perles, pp. 52-23); the second translation is supported by a few other cases in which a passive is used instead of an active (GK §5of). However, the phrase means literally "held by sword"—and thus can evoke images of warriors who are captives of their own weapons; see Stoop-van Paridon, pp. 163-364, who assumes an ironic allusion to "warriors" who are "effeminate men".

12 The allusion to Solomon's fear is even more striking because in the preceding scene (Song 3:1-1) the woman is described as most courageous, and in both cases the texts speak about possible dangers "in the nights" (3:1; 3:8); see Provan, pp. 152-253, 156-657; Zakovitch, 2004, p. 173 .

13 Frequently, scholars point to Jewish and Palestinian traditions about special dangers on the wedding night (or dangers associated with the desert); see Gerhards, pp. 235-537; 
scenario also raises the question of how the bride appreciates such a public ${ }^{14}$ (and fear-driven) prelude to her wedding. Finally, if the bed/palanquin is imagined to be empty, its protection just seems ridiculous and/or pretentious.

In 3:9-9o, the hints that the text might be mocking Solomon are less obvious, but they are still there. These verses are about Solomon's monly identified with the bed from 3:7 and understood as something like a palanquin. ${ }^{15}$ The description of the palanquin is formulated as a description of how Solomon has built it. Together with the mention of wood from the Lebanon and other precious materials, the passage is reminiscent of descriptions of Solomon's building activities elsewhere in the Hebrew Bible. Is this allusion meant to highlight Solomon's fame as a master builder? It might be. However, compared with Solomon's other building projects - the most famous being the temple and palace in Jerusalem (1 Kgs 6-6) - this one stands out as much smaller and significant primarily for himself. Thus, the allusion might also be meant to mock Solomon. Alerted by this suspicion, recipients might note that 3:9 includes the word "for himself" (לל), ${ }^{16}$ which is unusual. Normally biblical descriptions of building activities are just formulated with "he made ..." or the like (e.g., 1 Kgs 6:4). There is only one exception, in Eccl 2:5-5, 8, where King Qoheleth (= Solomon) is boasting about his building activities and thereby also draws attention to himself with is not without criticism of the king either, the parallel only substantiates the suspicion that Song 3:9 might be criticizing egocentrism. Moreover, 1 Kgs 7:8, which states that Solomon had built a house for the daughter of the pharaoh, whom he had married, draws attention to the fact that our verse says nothing about Solomon's bride. ${ }^{17}$

The silence about the bride continues in the following verses. That she is not mentioned in a text describing her husband's — and thus her own! —-wedding

Pope, pp. 435-537; Zakovitch, 2004, p. 176. However, these traditions are attested only later. Within the Hebrew Bible, the closest parallel is Ps 91:5-5, with the message that one must not fear the "danger of the night"; see Birnbaum, p. 259. Assis (p. 118) speculates that the verse might refer to the man's "fear of becoming closely intimate with his beloved". This seems far-fetched but would be in line with the thesis of a mocking song.

14 On the lack of intimacy, see Zakovitch, 2004, pp. 173-374, 178.

15 The general direction of this understanding can hardly be doubted. However, a hapax legomenon, and the exact meaning is a guess; instead of "palanquin" the word could also mean something like "canopied bed." For details, see Fox, pp. $125^{-526}$.

16 See Birnbaum, p. 259.

17 Loretz, 2004, p. 810, argues that originally the text read "for her", namely, the bride. However, this claim is not supported by any textual witness. 
is suspicious in itself. ${ }^{18}$ And it becomes even more peculiar in that the text mentions other women, namely, the Daughters of Jerusalem (Daughters of Zion) and Solomon's mother. The Daughters are mentioned a first time in 3:10, in a sentence that itself might be intended as a criticism of Solomon. Left unemended, the verse concludes the description of the palanquin with the statement that "its interior was inlaid with love from the Daughters of Jerusalem"

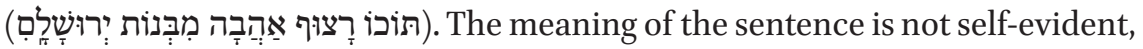
and thus it is often emended. No doubt, reading something like "stones"

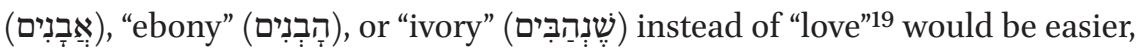
especially if the emended word ends with ם, so that the "from" (מן ) can be removed and the Daughters of Jerusalem moved to the next verse, creating a nice chiasm with the second mention of the Daughters in 3:11. However, there is no text-critical evidence to support this suggestion: the ancient versions all have "love" and keep the first mention of the Daughters in 3:10. ${ }^{20}$ Before emending the text, according to the text-critical rules, one thus must try to make sense of the text as it is. The suggestion to understand "love" as a reference to the

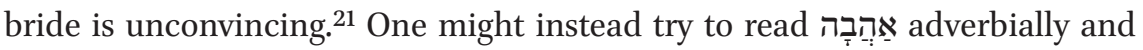
understand "with love" as a description of the Daughters' emotions when they paved the palanquin (with whatever material).22 Or one could understand "love" as the "material" with which the floor was inlaid. In this case, one would have to speculate about what exactly the metaphor stands for. Regardless of the details, the reference to love in close connection with the Daughters of Jerusalem is juicy in a text describing Solomon's wedding. Why does the text

18 Hence, some scholars "find" the bride between the lines. Some understand the bed in 3:6 as a reference to (or metaphor for) the woman (who is also identified by some with the ark of the covenant; see below, with n. 38); thus Holman, pp. 303-309; LaCocque, p. 98; Pope, p. 431; Vollmer, pp. 105-507; similarly Dirksen, p. 222; cf. also Rudolph, pp. 141-142, who argues that the text originally mentioned the bride but was altered when it was allegorized to the ark. Some scholars also see the bride referred to in 3:10 or 3:11; thus Barbiero, p. 158, and Hitzig, p. 52, who explain the word "love" in 3:10 as a reference to the bride; Holman, pp. 307-708, who argues that the description of the palanquin is also about the woman (e.g., taking "columns" as "legs"); and Vollmer, pp. 113-316, who argues that in 3:11 the bride is represented through the mother.

19 See Exum, pp. 149-950; Graetz, pp. 102-203; Krinetzki, p. 125, who also discuss other suggestions for emendations.

20 In addition one might point out that $4 \mathrm{QCant}^{\mathrm{a}}$ offers a text that indicates that there must have been a lacuna between the two mentions of the Daughters. The most likely place for this lacuna is before "Come out"; thus the reconstruction of both Tov (p. 200) and Elgvin (p. 18). If this reconstruction is correct it clearly shows that the first mention of the Daughters belongs to 3:10.

21 See above, n. 18.

22 Thus the Lxx; Delitzsch, p. 63; Ginsburg, p. 153; Longman, p. 138; Murphy, p. 149. 
mention women other than the bride? Is it an allusion to Solomon's love for many women (1 Kgs 11:1-1)?23

In 3:11, the Daughters are mentioned a second time. This time, the context is more harmless: the Daughters are invited to have a look at King Solomon. However, the mention of Solomon's mother crowning her son on the day of his wedding brings another highly suspicious detail to the fore. For one, why is the groom's mother mentioned but the bride is not?24 Furthermore, knowing the biblical tradition about Solomon, it is hard not to be reminded of Bathsheba helping her son to become king (1 Kgs 1). Again, there seems to be a mocking overtone in the text, this time making fun of Solomon as a mama's boy. ${ }^{25}$

\section{Problems with Solomon as a Cipher for the Nonroyal Lover}

Overtones are less clear than the explicit messages of a text, and trying to detect overtones always raises the danger of subjectivism. Pointing out elements in 3:7-71 that might be read as overtones, therefore, is not enough. To substantiate the thesis that the passage is mocking Solomon, in the following I will also address alternative explanations and demonstrate their weaknesses.

Most exegetes today take $3: 7-71$ to be a positive description of King Solomon's wedding. They either fully identify Solomon with the male lover described in the rest of the Song or they see him as a positive figure of identification in a more indirect way. ${ }^{26}$ No doubt, there are hints in the Song that speak in favor of this understanding, in particular its title, "the Song of Songs, which is Solomon's" (1:1), and the verses in which the male lover is described as a king $(1: 4,12 ; 7: 6 ; \mathrm{cf}$. 1:9). These royal descriptions of the male lover do not use the name Solomon, though. Besides 1:1 and Song 3 , Solomon is mentioned

23 See Birnbaum, p. 259; Heinevetter, p. 113; Provan, p. 154; Zakovitch, 2004, pp. 174, 178. See further Assis, p. 114; and Vollmer, pp. 112-213, who both understand "paved with love" as a reference to Solomon's many women, too, but interpret the reference not ironically and critically but positively.

24 That the text mentions the mother and not the father is in line with the rest of the Song. However, the mention of the mother instead of the bride remains suspicious. The rabbinic tradition knows the custom of crowning at weddings; see Keel, pp. 127-728; Pope, p. 448; cf. Isa 61:10; Ezek 16:12. A special role for the mother of the groom is not attested, though.

25 See Birnbaum, p. 260; Zakovitch, 2004, p. 179.

26 See Assis, pp. 109-919; Exum, pp. 138-851; Fox, pp. 120-027; Gerhards, pp. 238-839, 334; Hess, pp. 123-324; Hopf, pp. 166-673; Longman, pp. 131-139; Murphy, pp. 148-852; Peetz, pp. 16o-075; Spencer, pp. 71-11. 
only in 8:11-12. ${ }^{27}$ And here it is clear that he is not identical with the male lover. On the contrary, the text contrasts the male lover with the king. In detail, the verses are difficult, and interpreters disagree over their meaning. According to one plausible reading, the verses are spoken by the male lover, who points out that one woman ("my own vineyard") is enough for him and that Solomon can keep his thousand women (cf. 1 Kgs 11:3; Song 6:8-8). The text also mentions Solomon's "vineyard" and its guardians, often interpreted as a reference to Solomon's harem..$^{28}$ Of course, one might try to argue that 8:11-12 has nothing to do with 3:7-71. Given the possibility that the Song originated as a collection of originally independent love songs, it is also conceivable that this collection contains both a song that is positive about Solomon and one that is critical. In the concrete case of the two songs, however, the likelihood of this explanation loses plausibility, because they share several details in their descriptions of Solomon: both mention guards and allude to the king's riches and his amorous connection with women. Regardless, reading the Song as a unit-even if only as a unit through collection-makes it hard to escape the question of how the two songs about Solomon relate to one another. This question does not exclude the possibility that Solomon is depicted positively in 3:7-71 and negatively in 8:11-12-humans are often ambivalent in their feelings, after all. Despite the clear criticism of Solomon in 8:11-12, recipients thus might still understand Solomon as kind of a model for the two lovers in 3:7-71. What is not possible anymore, however, is a full identification of the male lover with Solomon, because the two are clearly distinguished in 8:11-12. The same conclusion, namely, that in 3:7-71 Solomon cannot be a cipher for the male lover described elsewhere in the Song, is also suggested by the fact that the Song describes the man and the woman as unmarried not only before the wedding of $3: 11$ but also after (see especially $5: 2-2 ; 8: 2$ ).

Elisabeth Birnbaum has presented further evidence that 3:7-71 is a mocking song about Solomon: she compares the woman's praise of her beloved in other passages in the Song with (a) how Solomon is depicted in 3:7-71 (and elsewhere in the Song) and (b) what he is famous for elsewhere in the Hebrew Bible. In both cases, there is no match. ${ }^{29}$ Particularly noteworthy is the observation that

\footnotetext{
27 See further 1:5, with a reference to "the curtains of Solomon".

28 See Exum, pp. 259-961; Fox, pp. 174-475; Zakovitch, 2004, pp. 279-982. Alternatively, one could argue that the woman is the speaker in 8:11-12 and uses "my vineyard" to refer to her beloved (and to her sexuality, respectively), criticizing Solomon not for his harem but for his interest in luxury and wealth; see Birnbaum, pp. 255-556; cf. Longman, pp. 218-820, with a mixture of the two possibilities. Whichever interpretation one follows, it remains that 8:11-12 underlines a contrast between Solomon and the male lover.

See Birnbaum, pp. 237-751.
} 
elsewhere the Song praises the mutuality of the lovers' relationship $(2: 16 ; 6: 3$; 7:11), connects love with taking risks (3:1-1; 5:2-2), and describes love as more powerful than any riches (8:7). All this stands in contrast to 3:7-71, with its silence about the bride, its description of Solomon's measures to protect himself (and/or his bride) against dangers, and its references to his power and wealth. Thus, the evidence speaks not only against an identification of Solomon with the male lover but also against the thesis that he might be praised as a model for the two lovers. ${ }^{30}$

\section{3}

Problems with Solomon as a Cipher for a Divine Lover

Modifying the thesis that Solomon is a cipher for the (human) nonroyal lover described elsewhere in the Song, a few scholars argue instead that in 3:7-71 Solomon is a cipher for a divine lover, namely God and/or the Messiah. In detail, different scholars nuance this thesis differently. ${ }^{31}$ However, in one way or another they all revitalize the tradition of allegorical interpretations of the Song, even though some insist that their reading is not allegorical but symbolic or the like. ${ }^{32}$ Regardless of exact terminology, the crucial point is that $3: 6-61$ is understood as a solemn text that describes the wedding between Solomon and his bride in a way that correlates to the "wedding" between God and Israel. Some scholars consider such an understanding only for 3:6-61, but others see love between God and humans described in the rest of the Song as well. Of course, this reading creates problems similar to those described in the section above, because this thesis is similarly difficult to harmonize with 8:11-12 and

30 Birnbaum, p. 251, concludes: "Ich komme also zu dem Ergebnis, dass die Frau meiner Meinung nach nicht die Sprecherin der 'Königstravestie' ist. Salomo ist nicht ihr Geliebter in königlicher Verkleidung, und mehr noch, wird auch nicht von ihr bewundert. Es ergeben sich zwei Möglichkeiten der Auslegung von 3,6-61: Entweder es handelt sich dabei um eine Art Spottlied, das die Frau oder ihr Geliebter auf Salomo anstimmt, oder andere—naheliegenderweise die Töchter Jerusalems selbst—bewundern Salomos Pracht, treffen damit aber nicht die Meinung der Liebenden. In beiden Fällen dienten die Verse dazu, Salomos Lebens- und Liebesweise jener der Liebenden gegenüberzustellen und davon abzugrenzen".

31 See Joüon, pp. 177-794; Robert/Tournay, pp. 19, 140-058; Schwienhorst-Schönberger, pp. 100-oo9; Heereman, 2016 (cf. Heereman, 2018, which was not available to me); Vollmer, pp. 93-321. See further Loretz, 1971, pp. 23, 62-23; Rudolph, pp. 138-842; Zakovitch, 2004, p. 171, who consider the possibility of an allegorical reinterpretation through editors; and Gerhards, passim, and Häner, pp. 13-32, who propose an allegorical understanding of the Song, though paying special attention only to Ps 45 (see n. 45), not Song 3 .

See Heereman, 2016, pp. 182-285. 
with the descriptions of love elsewhere in the Song. Nonetheless, in the following I will deal with allegorical interpretations of 3:6-61 and thereby show that the arguments for an allegorical/symbolic meaning of the Song are weak even in this passage.

The first verse (3:6), and the question of the identity of the person coming up from the wilderness, is crucial for proponents of an allegorical/symbolic understanding of 3:6-61. In Hebrew, the formulation with ("who is this?") makes clear that this person is a woman. Most allegorical/symbolic interpreters think of (personified) Jerusalem or Israel. Their arguments differ in details, but in one way or the other they all see allusions to Israel's salvation history, as do others who do not read the passage allegorically/symbolically. Some point out that the wilderness is the place where YHWH's love relationship with his people began (Jer 2:2; Hos 9:10; 13:5). The combination of "wilderness" (מִדְבָּר) and "to come up" (עָכָָה) are taken as reminders of Israel's wandering in the wilderness and, more concretely, the exodus from Egypt or the return from Babylon (Ex 33:1; Deut 1:21; Ezra 2:1). And the mention of "columns of smoke"

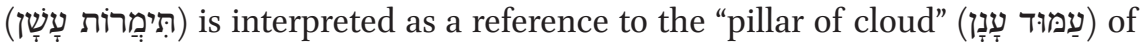
the exodus tradition (Exod 13:21; Num 12:5; Deut 31:15). ${ }^{33}$ All this is intriguing at first but is less plausible on a closer look. Both "wilderness" and "to come up" are words frequently used in the Hebrew Bible. Both can be related to the exodus and the return from exile, but the phrase "to come up from the wilderness" is not used in these contexts. Both words, obviously, are also used in many other contexts. For example, in the Song, "to come up" is used to describe how sheep come up $(4: 2 ; 6: 6)$ and how a man climbs a palm or mounts a woman (7:9). In 3:6, the choice of the verb is also influenced by the image of rising smoke, which in the Hebrew Bible is also described with the verb "to come up" (Josh 8:20; Judg 20:40; Isa 34:10). Likewise, it is doubtful on closer examination whether the columns of smoke are an allusion to the pillar of clouds. The use of different words and the plural instead of the singular speaks against it. Furthermore, the columns of Song 3:6 are fragrant-a motif not known from the exodus tradition. Though this might be a reminder of the tabernacle and the cult, it is yet another association, not congruent with the earlier ones. Furthermore, connections within the Song itself should be given more weight than such vague connections to other books. Here, the question "who is this?" is asked two more times, and in both instances it clearly aims at the female protagonist of the Song. In 8:5, where the question begins identically to the question in 3:6 ("who is this coming up from the wilderness?"), this is clear

33 In addition to those mentioned in n. 3o, see also Barbiero, p. 147; Davis, pp. 26o-o62; LaCocque, pp. 98-8o2; Pope, pp. 423-331; Zakovitch, 2004, p. 49. 
from the continuation ("leaning upon her beloved?"). In 6:10, where the question refers to dawn, sun, moon, and stars, the reference to the woman is obvious from the context and the phrase "terrible as an army with banners", which was already used in 6:4 in a direct speech to the woman. In 6:10 it is clear that the question is rhetorical in some way, intended to describe the woman in a numinous aura. In 3:6, the answer is less clear from the beginning; nonetheless, here as well, the question aims at describing the woman in a numinous aura.

Regardless of the precise interpretation, the numinous tone of $3: 6$ influences most interpretations of 3:7-71. Most exegetes read 3:7(-11) as a continuation of $3: 6,{ }^{34}$ imagining a solemn procession with the woman traveling in Solomon's bed/palanquin and the guardians around her to protect her against the dangers of the wilderness. However, the connections between 3:6 and 3:7-71 are scant. In 3:7-71 there is no indication that the bed/litter is moving, and the tone changes noticeably. At first, the "behold" in 3:7 might be taken as a signal that the following verse will answer the question posed in $3: 6$. Soon, however, it becomes clear that this might be a misunderstanding, because pointing to a piece of furniture can hardly answer a question about a woman..$^{35}$ That most interpreters still maintain that 3:7 must be some kind of answer to 3:6 primarily seems to be a stopgap: they thereby avoid having an unanswered question and a unit that consists of one verse only. ${ }^{36}$ Accordingly, some stretch the grammar and argue that pan also be used in the sense of "what". ${ }^{37}$ Along these lines, some allegorical/symbolic interpreters argue that 3:6-6o is about the ark of the covenant. ${ }^{38}$ Others try to identify the female figure of $3: 6$ with the bed/palanquin in other ways, ${ }^{39}$ but none of these explanations are convincing. Given that the question "who is this?" is not answered in either 6:10 or 8:5, in my view the most convincing explanation is that $3: 6$ and 3:7-71 did not originally

34 For the few exceptions, see n. 40.

35 That the noun מִָָּה is feminine does not help because the question in 3:6 is formulated not with "what" (מָה ) מִזי) but with "who".

36 To avoid the second problem, Fox, p. 119, has suggested reading 3:6 together with 3:1-1.

37 See Exum, p. 145; Longman, p. 133; Murphy, p. 149; Stoop-van Paridon, p. 157. On the problems with this explanation, see Dirksen, pp. 219-921.

38 See Joüon, pp. 177, 180; Rudolph, pp. 141-142; cf. Heereman, 2016, pp. 210-o11; LaCocque, p. 98 .

39 See Dirksen, pp. 221-124 (the bride is in the bed/palanquin, but she is not mentioned explicitly because the passage is interested primarily in Solomon and his royal status); Holman, pp. 303-309 (the bed/palanquin and the crown are metaphors for the bride); Vollmer, pp. ${ }^{105^{-507}}$ (the bed/palanquin is a throne and symbolizes Solomon's mother and bride, respectively). 
belong together. ${ }^{40}$ It might well be that whoever juxtaposed the two passages did so on purpose, to imply a connection. Along these lines, Yair Zakovitch argues that the allegorical/symbolic dimension of 3:6-61 was not there originally but was imparted by the redactors who put the two passages together. ${ }^{41}$ This is an intriguing theory, but it still has the problem that hints of an allegorical/ symbolic understanding are scant and that 3:7-71 contains several details that speak against it.

Most striking, again, is the silence about the bride. If the wedding mentioned in 3:11 were a reference to the covenant or love relationship between God and Israel, one would expect more attention to be paid to the bride/Israel. Even if we accept that she is being described in 3:6, the text does not say anything about the groom's love for his bride or about the bride's attitude towards her lover. This differs from other texts in the Hebrew Bible that employ the marriage metaphor, which talk about God's feelings and Israel's reactions (Isa 61:10; 62:3-3; Jer 2:1-1; Ezek 16:8-84; Hos 2:16-65; 11:4).

Another major problem with an allegorical understanding of 3:6-61 is the mention of Solomon's mother. ${ }^{42}$ The Hebrew Bible and other Jewish texts never refer to YHWH's mother. Unless this tradition is taken to be unique to the Song, Solomon cannot be a cipher for God. Some proponents of an allegorical/symbolic reading argue instead that Solomon stands for the messianic king. ${ }^{43}$ However, here as well a mother seems out of place. Though ordinary Davidic kings obviously have mothers, and the Christian tradition knows Mary, the mother of Christ, to my knowledge Jewish messianic texts never refer to a Messiah's mother. ${ }^{44}$

Some allegorical/symbolic interpreters point to Ps 45 as another biblical text that describes a messianic wedding as a symbol for the restoration of Israel. ${ }^{45}$ However, in my view this comparison does not support an allegorical/ symbolic reading of Song 3:6-61; on the contrary, it speaks against it. ${ }^{46}$ Most

40 See Birnbaum, p. 257; Bloch/Bloch, pp. 69, 159; Fox, pp. 119-921; Zakovitch, 2004, pp. 170, 173; cf. Assis, pp. 103-309.

41 See Zakovitch, 2004, p. 171.

42 See Peetz, pp. $173-374$.

43 Heereman, 2016, pp. 212-214; Robert/Tournay, pp. 145-546; Schwienhorst-Schönberger, pp. 107-709, all with reference to Ps 72.

44 Vollmer, pp. 93-317, integrates the mother into his allegorical reading by arguing that she stands both for the bride and for the land of Israel.

45 Gerhards, pp.497-703;Häner, pp.31-14; Heereman, 2016, p. 214; Schwienhorst-Schönberger, pp. 107-708; cf. Kingsmill, pp. 41, 264-465. Generally on the similarities between Ps 45 and the Song, see also Barbiero, p. 143; Longman, p. 133; Loretz, 1971; Murphy, p. 151; Zakovitch, 2004, pp. 5o, 62, 115, 171.

46 See Zakovitch, 2004, p. 5 . 
tellingly, Ps 45 includes statements that closely associate the king with God (Ps 45:7, 8), whereas Song 3 does not. It is only this close association that allows for an allegorical/symbolic reading of Ps 45 as being about the relationship between Israel and the messianic king/God. ${ }^{47}$ Furthermore, unlike Song 3, Ps 45 speaks about the bride: it describes her beauty and how she is brought to the king; it admonishes her to respect her groom; and it refers to the couple's children, who will become princes (Ps 45:10-07). Like Song 3, Ps 45 mentions other women and even alludes to the king's harem (Ps 45:10, $13,15-56)$. Nonetheless, it remains clear that the bride stands out among them. She alone is called "daughter" (Ps 45:11), and no other Daughters of Zion (Song 3:11) are mentioned beside her. Unlike Song 3, Ps 45 mentions neither the king's mother, who crowns him, nor his bodyguards, who protect him. Instead, Ps 45 highlights the king's sovereignty and power. Noteworthy in particular is Ps

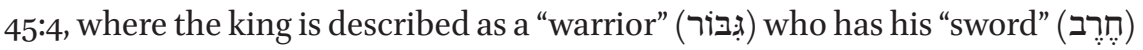
"at the thigh" (עַלי-ירָּד). The wording is similar to the wording in Song 3:7-7, a similarity that highlights the fact that Song 3 does not describe the king as a warrior but rather only mentions that he has warriors as bodyguards. This is peculiar regardless, and even more so if the king is supposed to represent God/ the Messiah (Isa 9:5; 42:13; Jer 20:11; Zeph 3:17).

\section{Summary and Consequences for the Overall Understanding of the Song}

The observations brought together in the last three sections are relevant not only for the interpretation of 3:6-61 but also for the overall understanding of the Song.

(1) The critical evaluation of the arguments for an allegorical/symbolic interpretation of 3:6-61 has shown that these arguments are weak and that there are aspects of the text that speak against reading it as being about the relationship between God/the Messiah and Israel (see above, 3). This is crucial beyond 3:6-61 because $3: 6-61$ is one of the passages most often considered to have allegorical/symbolic overtones. If the various assumptions cannot be verified even in this passage, with its alleged allusions to Israel's salvation history and the keyword "marriage," which is known as a metaphor for YHWH's relationship

47 Thus the interpretation of Hossfeld/Zenger, pp. 278-884, who argue that a preexilic coronation song praising the king and his close relationship to God (Ps 45:2-20, 17-78) was expanded in the postexilic period to describe the "wedding" (= new beginning) of the "daughter" (= Zion) to "the king" (= the messianic king or YHWH) (Ps 45:11-16). 
to his people from other texts, it is unlikely that there will be better evidence in other passages.

(2) The critical evaluation of how compatible 3:7-71 is with the rest of the Song has shown that it cannot be integrated into an ongoing story: it is impossible to identify Solomon with the male lover known from the rest of the Song, both because after 3:11 and its description of a wedding there are still units in the Song that describe the couple as unmarried and because 8:11-12 describes a contrast between the male lover and Solomon. Furthermore, 3:7-71 highlights aspects (like power and luxury) that are not praised elsewhere in the Song (see above, 2). Thus, the only possible conclusions are that 3:7-71 is an exception within the Song, the only passage that stands out from all the others, or that the Song was not composed as an ongoing story or the like but consists instead of different songs that are only loosely connected with each other. The first possibility requires an explanation of why the Song includes such an exception, which disrupts the rest of the text. The second possibility raises the question of why there is still so much coherence in the Song. These questions cannot be answered by an analysis of 3:6-61 alone. However, $3: 6$ provides some additional clues, both in that it is only loosely connected with 3:7(-11) — though in a peculiar way (see below) — and in that it shows similarities to 6:10 and 8:5 (see above, 3). Together with many other observations, these peculiarities in 3:6 speak in favor of the second possibility: that the Song grew together from different songs that originated independently. 48

(3) The critical evaluation of the thesis that Song 3:7-71 is a mocking song about King Solomon has shown that indeed such a reading is most likely. The passage does not criticize or ridicule Solomon explicitly, but it contains so many odd details that can be understood as having mocking overtones that it seems unlikely that they are all just coincidental (see above, 1) - even more so as Solomon is mocked/criticized in other texts from the Hebrew Bible as well (Deut 17:16-67; 1 Kgs 11:1-1; Eccl 1:12-2:26). Understanding 3:7-71 as a song mocking Solomon also explains why the passage stands out from the rest of the Song in other regards (see above, 2). The presence of a mocking song is significant for the overall understanding of the Song. It is a clear indication that the Song is also meant to entertain its recipients. No doubt, love is a solemn topic and the Song also contains statements that convey this (most obviously 8:6-6). Nonetheless, in many units the mood is light, and most of them contain playful elements, such as double entendres. A mocking song about Solomon fits into this picture well. The juxtaposition of 3:6 and 3:7(-11) can also be explained

48 For detailed argumentation (including an explanation of the Song's coherence), see Schellenberg, 2020 . 
along these lines. If the Song is meant to entertain its recipients, perhaps the question of 3:6 (cf. 6:10 and 8:5) remains unanswered so that the verse can be taken as some kind of a riddle..$^{49}$ If the Song was performed, ${ }^{50}$ perhaps the members of the audience were even invited to solve the riddle with their own answers. ${ }^{51}$ This might further explain the juxtaposition of 3:6 and 3:7(-11) as well: the two units have nothing to do with each other in and of themselves. The juxtaposition of the two, however, makes the "behold" at the beginning of $3: 7$ a signal that $3: 7(-11)$ is an answer to the question of $3: 6$. But the text continues "incorrectly", pointing out a bed instead of a woman - another riddle and another occasion for the Song's recipients to laugh.

\section{Works Cited}

Assis, E., Flashes of Fire: A Literary Analysis of the Song of Songs (LH BOTS 503; New York, 2009).

Barbiero, G., Song of Songs: A Close Reading, trans. M. Tait (VTSup 144; Leiden, 2011).

Birnbaum, E., “Just Call Me Salomo?' Hld 3,6-61 und 8,11-12 als Fallbeispiele der Hoheliedinterpretation", in L. Schwienhorst-Schönberger (ed.), Das Hohelied im Konflikt der Interpretationen (ÖBS 47; Frankfurt a.M., 2017), pp. 233-364.

Bloch, A./C. Bloch, The Song of Songs: A New Translation with an Introduction and Commentary (New York, 1995).

Davis, E., Proverbs, Ecclesiastes, and the Song of Songs (Westminster Bible Companion; Louisville, 2000).

Delitzsch, F., Hoheslied und Koheleth (BC 4/4; Leipzig, 1875).

Dirksen, P. B., "Song of Songs III 6-6", VT 39 (1989), pp. 219-924.

Elgvin, T., The Literary Growth of the Song of Songs during the Hasmonean and Early-Herodian Periods (CBET 89; Leuven, 2018).

Exum, C., Song of Songs: A Commentary (отL; Louisville, 2005).

Fox, M. V., The Song of Songs and the Ancient Egyptian Love Songs (Madison, 1985).

Gebhardt, C., Das Lied der Lieder: Übertragen mit Einfuihrung und Kommentar (Berlin, 1931).

Gerhards, M., Das Hohelied: Studien zu seiner literarischen Gestalt und theologischen Bedeutung (Arbeiten zur Bibel und ihrer Geschichte 35; Leipzig, 2010).

49 See Zakovitch, 2019, pp. 43-31.

50 On this possibility, see Schellenberg, 2014, pp. 143-353.

51 And this "invitation" stands even if the Song was not performed. Not only in 3:6, but generally, the Song leaves room for diverging interpretations - as reflected in its history of interpretation. Nonetheless, in my view, it is important to differentiate between interpretations that are closer to the text and others; hence this article's argumentation. 
Ginsburg, C. D., The Song of Songs: Translated from the Original Hebrew, with a Commentary, Historical and Critical (London, 1857).

Gordis, R., "A Wedding Song for Solomon", JBL 63 (1944), pp. 263-370.

Gottlieb, I. B., "Mashal Le-Melekh: The Search For Solomon", HS 51 (2010), pp. 107-727.

Graetz, H., Schir Ha-Schirim, oder das Salomonische Hohelied: Übersetzt und kritisch erläutert (Vienna, 1871).

Häner, T., "Salomo und das Lied der Lieder: Die Überschrift des Hoheliedes in kanonisch-spiritueller Perspektive", BN 172 (2017), pp. 13-32.

Heereman, N. S., “Behold King Solomon!' Symbolic Inner-Biblical Interpretation in Song 3:6-61", in A. Schellenberg/L. Schwienhorst-Schönberger (eds.), Interpreting the Song of Songs: Literal or Allegorical? (BTS 26; Leuven, 2016), pp. 181-119.

Heereman, N. S., "Behold King Solomon: A Symbolic-Diachronic Reading of Song 3:661 and 4:12-2:1" (Ph.D. diss., École biblique et archéologique française de Jérusalem and Université de Fribourg, 2018).

Heinevetter, H.-J., “Komm nun, mein Liebster, Dein Garten ruft Dich!” Das Hohelied als programmatische Komposition (Athenäums Monographien Theologie/BBB 69; Frankfurt a.M., 1988).

Hess, R. S., Song of Songs (всотWP; Grand Rapids, 2005).

Hitzig, D. F., Das Hohe Lied (Kurzgefasstes exegetisches Handbuch zum Alten Testament 16; Leipzig, 1855).

Holman, J., "A Fresh Attempt at Understanding the Imagery of Canticles 3:6-61", in K.-D. Schunk/M. Augustin (eds.), "Lasset uns Brücken bauen ...": Collected Communications to the XVth Congress of the International Organization for the Study of the Old Testament, Cambridge, 1995 (BEAT 42; Frankfurt a.M., 1998), pp. 303-309.

Hopf, M., Liebesszenen: Eine literaturwissenschaftliche Studie zum Hohenlied als einem dramatisch-performativen Text (ATANT 108; Zürich, 2016).

Hossfeld, F.-L./E. Zenger, Die Psalmen: Psalm 1-10 (NEB 29; Würzburg, 1993).

Joüon, P., Le Cantique des Cantiques (HAT 18; Lyon, 1909).

Keel, O., Das Hohelied (ZвK 18; Zürich, 1986).

Kingsmill, E., The Song of Songs and the Eros of God: A Study in Biblical Intertextuality (Oxford Theological Monographs; Oxford, 2010).

Krinetzki, G., Kommentar zum Hohenlied: Bildsprache und theologische Botschaft (BET 16; Frankfurt, 1981).

LaCocque, A., Romance, She Wrote: A Hermeneutical Essay on Song of Songs (Eugene, 1998).

Longman, T., Song of Songs (NICOT; Grand Rapids, 2001).

Loretz, O., Studien zur althebräischen Poesie 1: Das althebräische Liebeslied; Untersuchungen zur Stichometrie und Redaktionsgeschichte des Hohenliedes und des 45. Psalms (AOAT 14/1; Neukirchen-Vluyn 1971). 
Loretz, O., "Enjambement, versus und 'salomonische' Königstravestie im Abschnitt Canticum canticorum 3,6-61", in M. Witte (ed.), Gottund Mensch im Dialog:Festschrift für Otto Kaiser zum 8o. Geburtstag, vol. 2 (BZAW 345/2; Berlin, 2004), pp. 805-516.

Murphy, R. E., The Song of Songs: A Commentary on the Book of Canticles or the Song of Songs (Hermeneia; Minneapolis, 1990).

Nissinen, M., "Male Agencies in the Song of Songs", in O. Creangă (ed.), Hebrew Masculinities Anew (нвм 79; Sheffield, 2019), pp. 251-173.

Peetz, M., Emotionen im Hohelied: Eine literaturwissenschaftliche Analyse hebräischer Liebeslyrik unter Berücksichtigung geistlich-allegorischer Auslegungsversuche (нвs 81; Freiburg, 2015).

Perles, F., Analekten zur Textkritik des Alten Testaments: Neue Folge (Leipzig, 1922).

Pope, M. H., Song of Songs: A New Translation with Introduction and Commentary ( $A B$ 7; Garden City, 1977).

Provan, I. W., "The Terrors of the Night: Love, Sex, and Power in Song of Songs 3", in J. I. Packer/S. K. Soderlund (eds.), The Way of Wisdom: Essays in Honor of Bruce K. Waltke (Grand Rapids, 200o), pp. 150-067.

Robert, A./R. Tournay, Le Cantique des Cantiques: Traduction et Commentaire; Avec le Councours de A. Feuillet (EBib; Paris, 1963).

Rudolph, W., Das Buch Ruth, Das Hohe Lied, Die Klagelieder (KAT 17/1-1; Gütersloh, 1962).

Schellenberg, A., "Boundary Crossings in and through the Song: Observations on the Liminal Character and Function of the Song", in M. Chaney et al. (eds.), Reading a Tendentious Bible: Essays in Honor of Robert B. Coote (нвм 66; Sheffield, 2014), pp. 140-054.

Schellenberg, A., "Zur Einheit geworden: Eine These zur Entstehung des Hohelieds, gestützt auf Beobachtungen zu seinen Wiederholungen", in P. Van Hecke (ed.), The Song of Songs in Its Context: Words for Love, Love for Words (BE TL; Leuven, forthcoming [2020]).

Schwienhorst-Schönberger, L., Das Hohelied der Liebe (Freiburg, 2015).

Spencer, F. S., Song of Songs (Wisdom Commentary 25; Collegeville, 2017).

Stoop-van Paridon, P. W. T., The Song of Songs: A Philological Analysis of the Hebrew Book שִיר הַשְׁיִירים (ANESSup 17; Louvain, 2005).

Tov, E., "Canticles", in E. Ulrich et al. (eds.), Qumran Cave 4. XI: Psalms to Chronicles (DJD 16; Oxford, 2000), pp. 195-519.

Vollmer, C., "Wer ist die Braut in Hld 3,6-61?", BN 177 (2018), pp. 93-321.

Whedbee, J. W., The Bible and the Comic Vision (Cambridge, 1998).

Zakovitch, Y., Das Hohelied (HTKAT; Freiburg, 2004).

Zakovitch, Y., "Thrice Asked 'Who is She' in the Song of Songs", in idem (ed.), The Song of Songs: Riddle of Riddles (LHвотS 673; London, 2019), pp. 43-31. 